Int. J. Speleol. 19 (1990): 39-50

\title{
Isopoda (Crustacea: Isopoda: Microcharon, Jaera, Proasellus) and other fauna in hypogean waters of southern Cyprus
}

\author{
Boris Sket *
}

\section{SUMMARY}

Springs and wells in SW and S part of Cyprus were briefly surveyed. Chlorinity was $0.1-0.8$ p.p.t. Some isopods were found in collecting galleries of springs and in wells in calcarenites and in gravel deposits. These were Proasellus coxalis ssp. with some depigmented specimens, the probably stygobitic $P$. c. nanus ssp. n., poorly pigmented Jaera italica, and Microcharon luciae n. sp.; they were accompanied by the stygobitic amphipod Bogidiella cypria, by Turbellaria (Tricladida), by Copepoda (Cyclopoida), and rarely by some other animals (Pisidium sp., Oligochaeta). Only slightly depigmented Turbellaria Tricladida (cf. Dugesia sp.) occur in wells far from surface waters. Descriptions of new taxa are given.

\section{INTRODUCTION}

At the end of November 1988, 4 days were spent in field research in Cyprus. Some regions were surveyed for their possible caving potentials (however, without promising results) and particurlarly for fauna of their non-marine hypogean waters. The southern slopes of the Troodos Mountains, the westernmost part of the island between Pafos and Polis, and a zone between Limassol and Larnaka were visited. Since no data about the hypogean fauna of Cyprus have been available, I thought that there was reason for publication of our scanty results.

There are virtullay no perennial streams in Cyprus and natural hydrological conditions have changed greatly by the damming up of all important intermittent brooks, therefore we did not try to search tor interstitial fauna in gravel banks.

In igneous rocks of the Troodos we surveyed three small springs, including an artificial sulfurous, artesian well. Samples evidently contain only epigean fauna.

* Biology Department, Biotechnical Faculty, Aškerčeva 12, YU 61000 Ljubljana (Yugoslavia). 
There are numerous wells in the country, most of them quite wide; they have been mostly neglected by paesants and are in bad condition, as irrigation has recently been changed to that of surface water from artificial lakes.

In the region Geroskipou (= Yeroskipos) - Pafos — Lempa wells have been dug out in calcarenites, collecting small quantities of hypogean waters from the interface between calcarenite and underlying marls. Fauna consisted of Pisidium sp., Oligochaeta, Cyclopoida, and nearly normally pigmented Turbellaria Tricladida (? Dugesia sp.).

In the monastery of Agios Neofytos (NEE of Pafos) there is a collector gallery in limestones, causing enrichment of the originally natural spring. The stagnant water in residual pools in the gallery is highly calcified, thus surface calcitic incrustations have built a thick layer of crusts on the bottom. Carcasses of Amblypygi were found on the bottom. The aquatic fauna consisted of Oligochaeta, Jaera italica, and small specimens of Bogidiella cvpria G. Karaman.

In Arothes and Kritou Tera (Akamas region) there are perennial springs at the contact of poorly karstified reef limestones and underlying clavs. The temperature of the spring water was $17^{\circ} \mathrm{C}$. Proasellus coxalis was found outside and in the collecting galleries of the springs; it exhibited some degree of depigmentation, and was accompanied bv Oligochaeta and young leeches Dina cf. lineata.

A meagre spring in chalks in Agia Mavri (at Perapedhi, NW of Limassol) contained specimens of the probably stygobitic Proasellus coxalis nanus ssp. $\mathrm{n}$.

Some wells in gypsum between Moni and Zygi (ENE of Lemesos) gave no aquatic fauna.

Several quite deep wells in gravel deposits were surveyed in the coastal strip at Argaka (NE of Polis), and between Larnaka and Zygi (SW of L.). Their chlorinities were $0.6-0.8$ p.p.t. versus $0.1-0.4$ in other waters. In most of them we found Oligochaeta and Cyclopoida, but Turbellaria Tricladida (? Dugesia sp.) seemed to also occur quite regularly (Argaka, Thromolaxia near Larnaka).

A well in shallow gravel deposits at the mouth of a dry valley, ca. $100 \mathrm{~m}$ from the seashore in Amathous, was the only locality exhibiting the doubtlessly stygobitic fauna, consisting of Microcharon luciae sp. n., (?) Proasellus sp. (eyeless; manca), Bogidiella cypria (remarkably larger specimens than in A. Neofytos; cf. Karaman, 1989), Copepoda, Ostracoda, Oligochaeta. Chlorinity was 0.2 p.p.t.

The main karstic spring of the Loutra tis Afrothitis (Aphrodite's Bath, WNW of Polis) was not suitable tor sampling, and no animals were tound in small accessorv springs; the short brook is inhabited by numerous snails (Theodoxus [Neritaea] anatolicus [Recluz], Melanopsis sp., ct. Pseudamnicola sp., ct. Potamopvrgus sp.), Oligochaeta, Hirudinea (Dina ct. Lineata); and Crustacea (Jaera italica, Echinogammarus sp.). Chlorinity was 0.3 p.p.t. 


\title{
TAXONOMIC DESCRIPTIONS
}

\author{
Microcharon luciae sp. n.
}

Material: well in Amathous, E of Limassol - Lemesos, Cyprus; chlorinity 0.2 p.p.t.; numerous male and female specimens (most without antennae and uropods). Holotypus: a dissected male of $1.3 \mathrm{~mm}$.

Etymology: dedicated to my wife Lučka (= Lucia), who stoically sacrificed most days of the short family vacation for inspection of wells.

\section{Description}

Body slender, males $1.2-1.4 \mathrm{~mm}$ and females $1.3-1.5 \mathrm{~mm}$ long, width $10 \%$ of the length, pleotelson slightly wider. Pereionite I less than half as long as broad, its anterior angles anterolaterally extended and rounded; pereionites IV-V shorter than wide, II-III slightly longer and VI-VII up to $30 \%$ longer than wide. The free pleonite not much shorter than pereionite I. Pleotelson longer than pereionite VII, longer than wide, subrectangular, with slightly convex margins and broadly rounded angles, with approximately 7 long setae along each lateral margin and 2 pairs of setae between both uropods.

Antenna I 6-articulate. Its article 1 nearly cylindrical, with 1-3 short setae in its laterodistal part. The equally long and wide article 2 also with 1-2 such setae and with a long plumose seta on its mediodistal protuberance. Articles 3-5 with successively: a plumose seta, a simple seta, and a mediodistally inserted, very long aesthetasc. Article 6 in males distally has 2 aesthetascs and a long seta; in females, it bears only 1 aeshetasc, 3 setae, and a subterminally inserted plumose seta.

Antenna II approximately $40 \%$ of body length in both sexes; with articles 1-3 slightly thicker than others, squama variable in length, it may reach the laterodistal end of the next article, with 2 setae; last article of the shaft is by far the longest, in a male remarkably longer than in a female. Flagellum with 9 articles in male and with 8 articles in female. Antennal setae are shorter than flagellar articles in the female, while some of them are longer in the male.

Mandible's pars mollaris broadly conical, with 1-2 long apical spines. Both pars incisiva and lacinia mobilis of the left mandibula 4-dentate; its lacinia mobilis 4-dentate and followed by 1 strong and knee-shaped pectinate spine and by 4 strong setae. Right mandibula similar, but without lacinia mobilis and with at least 2 of its knee-shaped to slightly sigmoid spines/setae pectinate, they are getting progressively longer and straighter towards the pars mollaris. Palpus with articles 1-3 in lengths ratio 100:195:135; article 2 with 2 subapical setae on its inner side, article 3 with a short seta in its proximal part and with a row of 4 long setae in its distal third, its inner side is finely setose. 
The outer endite of maxilla I 2.5 times as wide as the inner one, with 10 long and slightly curved spines, some pectinate, along its apical margin and with up to 2 long submarginal setae in each the proximal and apical part of its inner side, and 1 near its outer margin; the inner endite with 3 apical spines and with up to 2 subapical and 2 outer submarginal setae.

All endites of maxilla II approximately equally long. The inner one is widest, it bears 7 strong apical and medio-distal setae, at least 1 of them is pectinate, getting progressively shorter medially, and with up to 6 shorter and weaker setae along its distal and median margins; the central and outer endite with 3-4 apical setae each.

The maxilliped's endite reaches beyond the medio-distal angle of the palpus article 2, with a denticulated distal margin, bearing 3 long latero-distal spines and approximately 8 short distal and subdistal setae; 2 retinacula present. Palpus with very wide, nearly semicircular articles 2+3, apical articles narrow; all articles with groups of 2-5 setae in their distal and/or subdistal parts.

Basipodites (article 1) of anterior pereiopods very broad, II nearly semicircular, they are narrower in posterior pereiopods. Pereiopod I in 2 males and 1 female approximately $25 \%$ of body length, pereiopod VII in 1 male $30 \%$ of it; pereiopod II approximately equals pereiopod I in a male and pereiopod VII in a female, respectively. The lengths of articles, measured between articulations are $100: 75: 50: 100: 80$ to 90 : 50 in the pereiopod I and $100: 75: 30: 90: 75: 35$ in the pereiopods II and VII. Dactyli with socles longer than wide, longer than their smaller claws and shorter than main ones; in pereiopod I with 4 subdistal and 1 inner seta, in VII with only 3 subdistal setae; other articles with 1-4 spines and/or setae each.

Male pleopods I proximally twice as wide as distally from their triangular part, which is $2 / 5$ of the gonopod's length. Distal part only $20 \%$ of the gonopod's length wide, without a gap between both halves, apically truncated, with broadly rounded lateral angles, medially longer, thus distal margins directed slightly proximo-laterally; 2 pairs of long and 1 pair of short medio-subapical setae, and a pair of warts with a short seta each immediately proximally from mentioned setae; 3 pairs of long subdistal setae.

Male pleopod II with a narrow sympodite, its lateral to distal borders convex, the medio-distal corner broadly rounded. Endopodite narrow, with a long and slightly sigmoid tip, reaching far beyond the sympodite's tip.

Female pleopod II ovoid, distally emarginate and with a pair of setae.

Pleopod III with exopodite slightly curved inward, with a short apical seta, inner protuberances of the proximal article not very distinct. Endopodite ellipsoid, without setae, markedly shorter than exopodite. Pleopod IV sausage-shaped. 


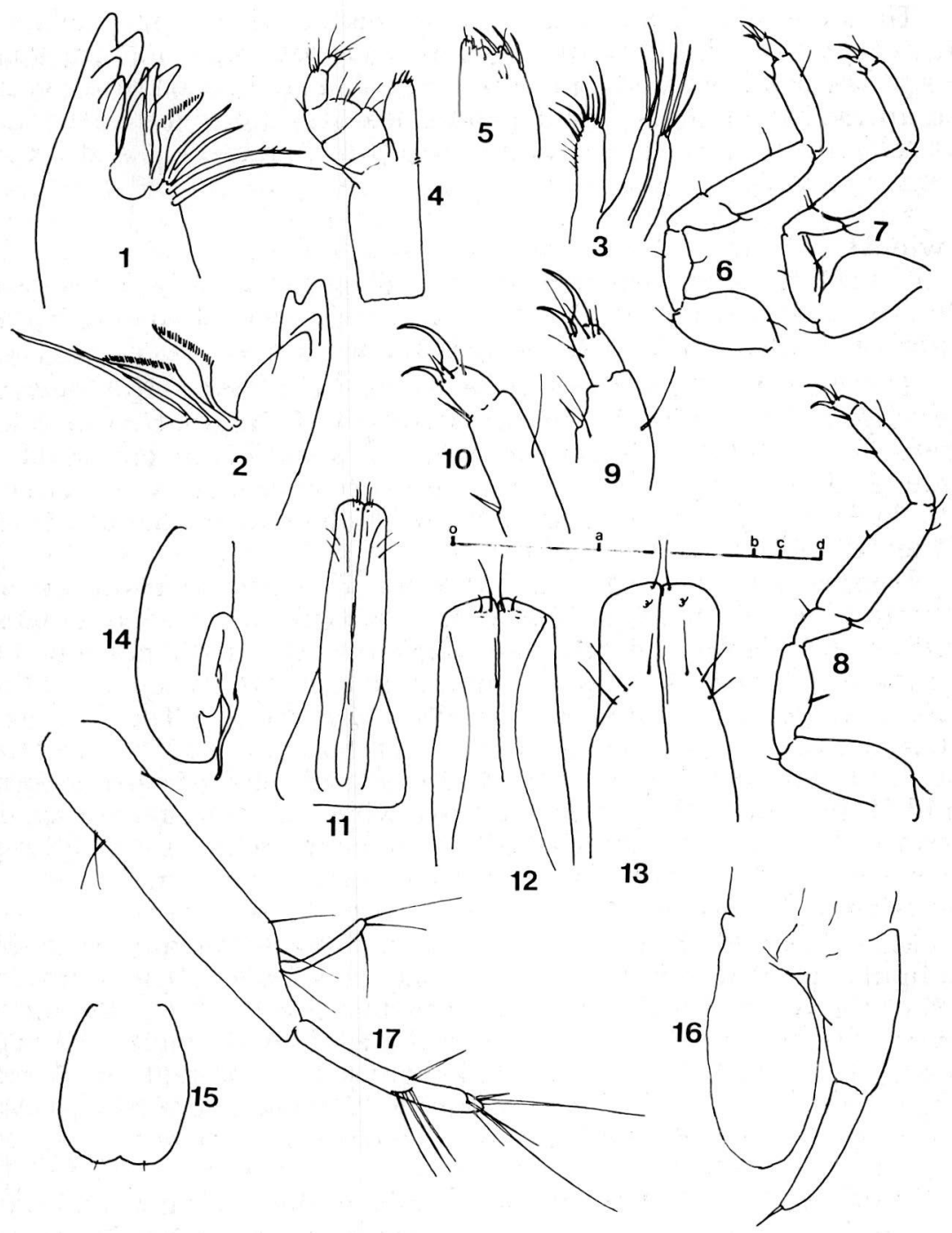

Plate 1 - Microcharon luciae sp. n., Amathous, Cyprus: 3, 6-7, 14, 16, holotype $\delta 1.3 \mathrm{~mm}$;

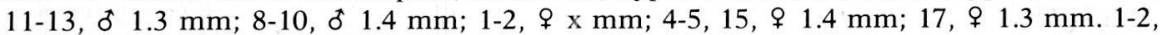
apical parts of both mandibles; 3 , maxilla II; 4-5, maxilliped and apical part of its endite; 6-8, pereiopods I, II, and VII; 9-10, apical parts of pereiopods I and VII; 11-13, male pleopod I and its apical part in different levels; 14, male pleopod II; 15, female pleopod II: 16, pleopod III; 17 , uropod. Scales: a $(0.2 \mathrm{~mm}) 15$; b $(0.2 \mathrm{~mm}): 4,6-8,11,14,17$; c $(0.1 \mathrm{~mm})$ $3,5,9-10,12-13,16$; d (0.05 mm) 1-2. 
Uropods with the parallel-sided sympodite slightly longer than the pleotelson ( $120 \%$ of its length), bearing 1 lateroproximal, 2 medioproximal, and 3 laterodistal and distal setae. Endopodite slightly over half the sympodite's length, with 4 long setae in its middle and 5 short setae distally and subdistally. Exopodite only $20 \%$ of the sympodite's length and approximately equal to its width, with 3 distal to subdistal setae.

\section{Remarks}

The most important features of the species are the 6-articulated antenna I, wide pereiopod basipodites, narrow male pleopodes I with a simply rounded apex, longer medially than laterally, male pleopod II with a rounded sympodite and a long and slightly sigmoid endopodite, emarginate female pleopodes II with a pair of apical setae, elongated uropod sympodites and particularly the small endopodite of the pleopod III. While other characters occur quite often in different combinations, such a small pleopod III endopodite is much rarer, it is the most similar in M. halophilus Birštejn \& Ljovuškin 1965. As it has been already pointed out (e. g. Pesce, 1979), the Microcharon spp. exhibit very different combinations of character states, which mostly do not allow us to search for exact relations within the genus.

\section{Jaera italica Kesselyak 1938}

Material: collecting gallery of the spring in Agios Neofytos Monastery, NE of Pafos, W Cyprus; chlorinity 0.1 p.p.t.; 5 males; brook of the Loutra tis Afrothitis, W of Polis, W Cyprus (epigean locality); chlorinity 0.3 p.p.t.; numerous specimens.

All specimens from the hypogean locality in Agios Neofytos are less than $2 \mathrm{~mm}$ long and narrow, which characterizes young males; although the primary and secondarv sex characters may already be developed. Thus, their size approximately equals that trom surtace specimens; the hypogean specimens are partly depigmented, with only some narrow transverse stripes of dark pigment. This is similar to some cave populations in Yugoslavia and probably also in Mallorca (cf. Sket, 1986; Gourbault \& Lescher-Moutoue, 1979).

Adult males from Loutra tis Afrothitis differ in some details from the original description; the series of spines on the male pereiopod IV is e. g. shorter than in type specimens from Sicilia. Since patterns of variability seem to be very different in different parts of the species' area (cf. Veuille \& Kocatas, 1979), the establishment of a new Cypriot subspecies would require a previous study of variability in the whole species range.

\section{Proasellus coxalis (Dollfus) ssp.}

Material: collecting gallery of the spring in Arothes, Akamas region, $\mathrm{W}$ Cyprus, numerous specimens of all ages; pond at the spring in 


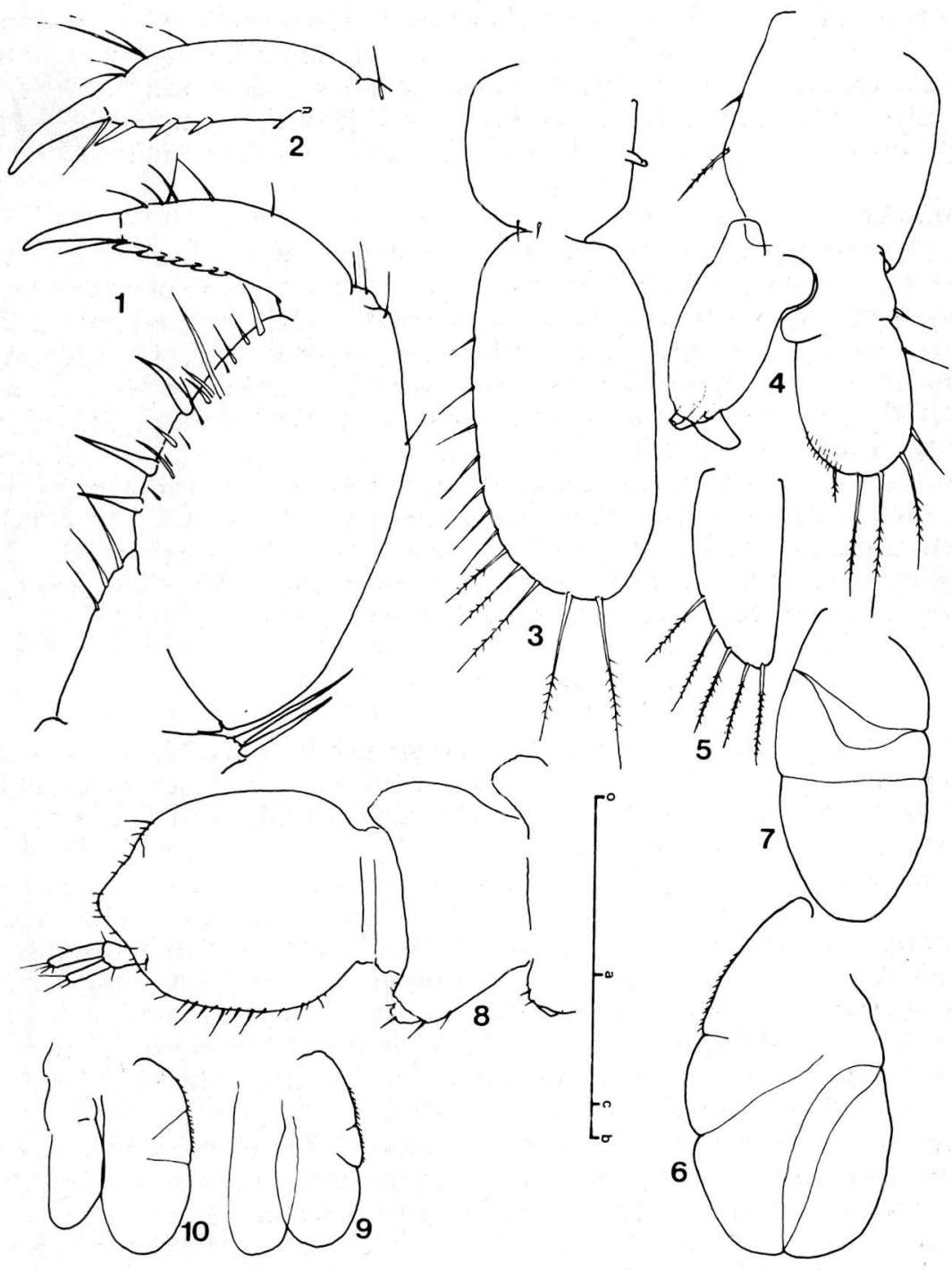

Plate 2 - Proasellus coxalis nanus ssp. n., Agia Mavri, Cyprus: 1, 3-4, 8, holotype $\delta 3.3 \mathrm{~mm}$; 6-7, o $2.7 \mathrm{~mm} ; 2,5$, $93.3 \mathrm{~mm} ; 9$, manca $0.9 \mathrm{~mm}$. 1, apical parts of male pereiopod I; 2 , dactylus of female pereiopod I; 3-4, male pleopods I-II; 5, female pleopod II; 6-7, pleopods IV-V; 8 caudal part of the body; 9 , pleopod IV. ? Proasellus sp., Amathous, Cyprus: 10 , manca $1.0 \mathrm{~mm}$, pleopod IV. Scales: a $(0.5 \mathrm{~mm}) 8$; b $(0.5 \mathrm{~mm}) 5-7$; c $(0,2 \mathrm{~mm}) 1-4,9-10$. 
Arothes (epigean habitat), 5 specimens; collecting gallery of the spring in Kritou Tera, Akamas Region, W Cyprus, numerous specimens of all ages.

Specimens trom springs in the Akamas region show different degrees of pigmentation or depigmentation; some of them are completely colorless with only 2 pigmented ommatidia in each eye. Male pleopod I with 1-2 laterodistal setae on the sympodite, exopodite narrow and long, without a submarginal row of setae along the median margin, its medioproximal corner moderately marked. Sympodite of the male pleopod II with up to 4 medio-distal setae, exopodite remarkably longer than endopodite. Pleopod IV with a small area, linea areae reaches the distal margin at its middle, linea transversalis incomplete or reaching the median border, not confluent with linea areae. Linea duplex in pleopod $\mathrm{V}$ nearly symmetrical, its both ends equally away from linea transversalis.

Since the recent subspecific taxonomy in this species is somehow chaotic (cf. Moroli et al., 1988), a comparison of this Cypriot populations with others is very difficult and unproductive. Anyway, establishment of a subspecies would require a redescription of the type subspecies as well as an equal treatment of all known populations and study of individual and geographic variability within already established subspecies.

\section{Proasellus coxalis nanus ssp. $\mathrm{n}$.}

Material: small spring in chalk of Agia Mavri, at Perapedhi, SW Cyprus; chlorinity 0.2 p.p.t.; 8 juveniles and adults. Holotypus: male, $3.3 \mathrm{~mm}$.

Etymology: nanus = dwarfish in Latin, for its small size.

\section{Description}

Body completely white, 1-2 brown pigmented ommatidia. Body small, males up to $3.5 \mathrm{~mm}$ long, females probably longer (judging by remains of a female with marsupium), slightly elongated in comparison with epigean populations, largest width equals $20 \%$ of body length; pleotelson broadly ellipsoid, with very marked, triangular part between both uropods, irregularly spinose along margins.

Antenna I with a 5- to 6-articulated flagellum, 3 distal articles with single aesthetascs, which are shorter than supporting articles. Antenna II $80 \%$ of body length, with up to 31 flagellar articles in males and 26 in females.

Pereiopodes I normally built, in males with 3 large palmar spines and moderate setation along the palmar margin; dactylus with 6 inner spines which lie down along the article; in females there are only 2 large palmar spines and the only 3 inner spines on dactylus jut out.

Pereiopod IV only slightly modified, strong but not curved, with 
2-3 inner spines on its dactylus. Pereiopod VII slightly over $50 \%$ of body length, not elongated, articles 1-2 approximately equal in length and longer than articles 4-5; with 3-4 long spines along the inner edge of article 5 and with 2 spines on dactylus.

Sympodite of the male pleopod I as long as wide, with 1 retinacular hook and with 2 short laterodistal setae. Exopodite elongated, twice as long as wide, with 4-5 pennate setae in the distal part and with 7-9 setae along the lateral margin.

Sympodite of the male pleopods II slightly longer than wide, with 1-2 setae mediodistally. Both rami equally long. Endopodite normally built but comparatively thick, the large apophyse directed laterally, the funnel is distal and slightly curved medially. Exopodite with 1 seta on the proximal article; distal article broadly ovoid, with 4 short and long pennate setae and 1-2 smooth setae, and with a mediodistal field of fine setation.

Female pleopod II rounded triangular, twice as long as wide, with 5 pennate setae disto-laterally.

Exopodites of pleopodes IV-V comparatively narrow, nearly twice as long as wide. Pleopod IV with the area small to medium large, linea areae reaching the distal margin in its middle or more latero-distally, it reaches the median margin in its proximal half; emargination of the linea transversalis slightly distal and emargination of the linea conjungens slightly proximal to middle of the outer margin. Pleopod V with very nonsymmetrical linea duplex, its median emargination pushed distally.

Uropods $35-60 \%$ of the pleotelson length, sympodite and exopodite equally long, endopodite slightly longer, all articles moderately setose.

\section{Remarks}

The new subspecies is generally built like other races of $P$. coxalis, but some peculiarities allow its separation without a revision of all related taxa. I attribute it to the species $P$. coxalis for its similarly built pleopodes I-IV and pereiopods. The difference between this subspecies and the type subspecies can be bridged by a series of others. However, a comprehensive revision will be needed to establish relationships between the many related Mediterranean species and subspecies clearly.

Peculiar to $P$. c . nanus are the small and elongated body in combination with a normal development of spines on I pereiopod dactyli, equally long rami of male pleopods II, narrow pleopods IV-V, asymmetrical linea duplex in pleopod V. In most small hypogean species and subspecies, derived from $P$. coxalis, the inner spines on dactyli of pereiopod I are slender and jut out (cf. P. minoicus, Pesce \& Argano, 1980; P. c. aoualensis Dia \& Henry, 1984), which is a pedomorphosis. In P. c. nanus only the number of these spines is smaller than in large races or species. The less differentiated pereiopod 
IV is pedomorphic here. Similarly proportioned male pleopods II can be found in P. c. cyanophilus (Dudich, 1925) but in P. c. nanus this is obviouslv a consequence of unchanged allometric growth and nanism, since the exopodite in other taxa gains in length with growing body length. The proportions are similar in $P$. c. aoualensis, where both rami are narrower than in P. c. nanus and the exopodite setation is different.

The population is certainly not sympatric to (resp. a portion of) the Arothes population. Both localities are approximately $45 \mathrm{~km}$ apart. They belong to different drainage areas: Arothes spring drains to the $\mathrm{W}$ while the Agia Mavri region drains to the Episkopi Bay in the S; the petrographic diversity and the feeble development of the subsurface drainage in the area (cf. Pantazis et al., 1979; Tullstrom et al., 1970) excludes any hypogean connections.

\section{Proasellus? coxalis ssp.}

Material: well in Amathous, E of Limassol, S Cyprus, 2 specimens of manca stage.

\section{Description and remarks}

Both specimens are completely pigmentless, eyes not discernible. The pleopod IV exopodite resembles the $P$. anophthalmus group: it is narrow, only two lineae are visible (linea areae probably not yet developed), one of them divides the exopodite nearly transversally in two subequal parts; another linea begins in the middle of the proximal part of the outer margin and joins the first linea. Pleopods I-II and V are not yet characteristically developed.

However, in $P$. coxalis, in the first stages with 7 pereiopods, the pleopods IV are already shaped similarly to those in adults. But a manca of $P$. c. nanus has pleopods IV built so similarly, that at least the conspecifity of the Amathous population with P. coxalis is well possible.

\section{SUMMARY AND CONCLUSIONS}

It is however probable, that more extensive explorations, particularly in the karstified Kyrenia Range in the north, will yield some interesting news. Nevertheless, the now established poverty of the old hypogean fauna would be in accordance with the modest age of the island (not continuously existing at least till the middle Miocene, cf. Schmidt, 1956; Dercourt et al., 1985) and with feeble or even never existing connections with the mainland, except during the Miocene desiccation of the Mediterranean.

The Microcharon sp. and Bogidiella sp. could be of quite recent marine provenience. Proasellus coxalis evidently exhibits good spreading abilities by nonaquatic means - consider its occurrence in Madeira and its recent spread into Central Europe. It need not be 
bound to man as supposed by Herhaus (1977), but can be supported by more natural means like water fowl (cf. Segerstrale, 1954 for Gammarus lacustris; Knorre, 1979 for $P$. coxalis on small distances). Similarly to the situation in NW Yugoslavia, this species penetrated hypogean waters, which resulted in partly depigmented populations and in one quite aberrant race $P$. c. nanus. The asellid specimens from the well in Amathous are enigmatic, as they could belong to another, stygobitic and endemic species. Interesting but not unique is the occurrence of Jaera italica in inland hypogean waters, since it mostly inhabits coastal brackish springs; both Cypriote localities are limnic or slightly oligohaline (chlorinity $0.1-0.3$ p.p.t.). The quite common and wide occurrence of only slightly depigmented specimens of tricladid turbellarians (? Dugesia sp.) in different types of groundwaters, tar trom any surface waters, in chlorinities of up to 0.8 p.p.t., is also interesting.

\section{ACKNOWLEDGMENT}

The field work logistics were kindly supported by the Geological Survey Department, Ministry of Agriculture and Natural Resources of the Republic of Cyprus, and its director, Dr. G. Constantinou. I am particurlarly glad to have enjoyed the friendly companionship and professional guidance of the senior geologists S. Afrodisis and K. Avramides.

\section{REFERENCES}

DERCOURT, J., L. P. ZONENSHAIN, L. E. RICOU et al. 1985. Presentation de 9 cartes paleogeographiques au 1/20 $000000^{e}$ s'etendant de l'Atlantique au Pamir pour la periode du Lias a l'Actuel. Bull. Soc. geol. France (8) 1 (5): 637-652.

DIA, A. \& J. - P. HENRY. 1984. Nouvelles donnees sur les Asellides du Liban (Crustacea, Isopoda). Annls Limnol. 20 (3): 193-198.

DUDICH, E. 1925. Systematische Studien an italienischen Aselliden. Ann. Mus. nat. hung. 22: 281-301.

KARAMAN, G. S. 1989. Bogidiella cypria, new species of the family Bogidiellidae from Cyprus Island in the Mediterranean Sea. Glasn. Odiel. prir. Nauka CANU 7: 7-23.

KESSELYAK, A. 1938. Die Arten der Gattung Jaera Leach (Isopoda Asellota). Zool. Jahrb. Syst. Oekol. 71:219-251.

KNORRE, D. v. 1979. Die Verbreitung von Proasellus coxalis (Dollfus, 1892) (Crustacea, Isopoda, Asellidae) in Thuringen - Ein Beitrag zur Problematik der Expansion einer Tierart. Zool. Anz.202 (3-4): 185-198.

GOURBAULT, N. \& F. LESCHER-MOUTOUE. 1979. Faune des eaux souterraines de Majorque. Endins, 5-6: 43-54.

HERHAUS, K. - F. 1977. Die Verbreitung von Proasellus coxalis (Dollfus, 1892) (Crustacea, Isopoda, Asellidae) in Mitteleuropa. Zool. Anz. 199 (5-6): 314-324.

MOROLI, M., A. LOY \& R. ARGANO. 1988. Variazione geografica in Proasellus coxalis (Dollfus): analisi multivariata di variabili morfometriche (Crustacea, Isopoda). Boll. Zool. 55 (Suppl.): 76.

PANTAZIS, T. et al., 1979. Geological map of Cyprus. Geological Survey Dept., Cyprus, Limassol.

PESCE, G. L. 1979. The first microparasellid from subterranean waters of Iran, 
Microcharon raffaellae n. sp. (Crustacea, Isopoda). Vie Milieu, 28-29 (2), ser . C: 237-245.

PESCE, G. L. \& R. ARGANO. 1980. Nouvelles donnees sur les asellides de la Grece continentale et insulaire (Crustacea, Isopoda). Bull. Zool. Mus. Univ. Amsterdam (7 (5): 49-59.

SCHMIDT, W. F. 1956. Zur Morphologie und Landschaft von Cypern. Petermanns geogr. Mitt., 100: 268-277.

SEGERSTRALE, S.G. 1954. The freshwater amphipods Gammarus pulex (L.) and Gammarus lacustris G. O. Sars in Denmark and Fenoscandia - a contribution to the late and post-glacial immigration history of the aquatic fauna of Northern Europe. Soc. Sci. Fenn. Commentat. biol. 15 (1): 91 pp.

SKET, B. 1986. Ecology of the mixohaline hypogean fauna along the Yugoslav coast. Stygologia, 2 (4): 317-338.

TULLSTROM, N.H.O. et al. 1970. Hydrogeological map of Cyprus. Geological Survey Dept., Cyprus, Limassol.

VEUILLE, M. \& A. KOCATAS. 1979. Les Jaera (Isopodes, Asellotes) des cotes de Turquie, etude comparative et biogeographique. Vie Milieu, 28-29 (4), ser. AB: 597-611. 